\title{
Changing Dynamics in Myanmar's Ethnic Peace Process and the Growing Role of China
}

\author{
N. Ganesan
}

The Myanmar peace process between the government and the ethnic armed groups has undergone some major changes since October 2016. Whereas the armed groups were previously distinguished between those that had signed the Nationwide Ceasefire Agreement (NCA) in 2015 and the non-signatories, the situation is much more complicated now. The formation of the Northern Alliance in late 2016 led by the United Wa State Army (UWSA), which had previously been outside the peace process, is the most important change. This development has in turn weakened the United Nationalities Federal Council (UNFC), which represented the nonsignatories, and has also led to the growing involvement of China in the peace process, introducing a new external dimension.

Keywords Northern Alliance, Myanmar peace process, ethnic armed groups, Nationwide Ceasefire Agreement, Myanmar-China relations

\section{Introduction}

The Myanmar government's Nationwide Ceasefire Agreement (NCA), which was concluded between the Thein Sein government and eight out of the sixteen ethnic armed groups that were negotiating with the government, was the culmination of a long process of negotiations that began in 1989 following the collapse of the Burma Socialist Programme Party (BSPP) government led by General Ne Win. Since this Agreement came into being, the ethnic armed groups have generally been divided into signatories and non-signatories. Alongside these two broad groups, there were other groups that were not a part of the process. This was true of smaller groups that the military did not recognize, and also included the largest of the ethnic armed groups, the United Wa State Army (UWSA), which maintained for a long time that the bilateral ceasefire agreement which it had previously signed in 1989 with the government was sufficient and working. Consequently, the UWSA remained aloof from the government endorsed peace 
process.

A series of developments that occurred in late 2016 has changed the dynamics of this previous equation. For the first time the UWSA began by trying to play a brokerage role between the government and the non-signatories that were part of the United Nationalities Federal Council (UNFC). In doing so, it began to align more with the non-signatories and became involved in uniting the remaining groups and playing a leadership role. This transformation occurred as the military's fighting with the Kachin Independence Army (KIA) intensified together with a similar deterioration in the relationship between the military and the Myanmar National Democratic Alliance Army (MNDAA) and the Ta’ang National Liberation Army (TNLA), which represents the Palaung ethnic group. As a result of attacks and counterattacks by both sides and an existing understanding among the northern ethnic armed groups, a Northern Alliance emerged in October 2016. This Northern Alliance, now led by the UWSA, has formed its own negotiating team and demanded that the government revisit the terms of the NCA.

The current government, led by the National League for Democracy (NLD) and the military, has two issues related to political violence to deal with-the first involving the Muslim residents of Rakhine state who have been systematically subjected to deprivation and exclusion, and the second involving the ethnic armed groups which this article addresses. Nonetheless, the NLD government has clearly identified the resolution of the conflict with the ethnic armed groups as its foremost policy priority. It has also clearly indicated that the NCA provides the way forward for the resolution of the ethnic conflict while trying to accommodate the new Northern Alliance.

Also, China has increasingly become more involved in the ethnic peace process. There are many reasons for the Chinese interest. The first is that the process itself is important for China's peace and security along the long and porous China-Myanmar border. The second reason is that many members of the Northern Alliance like the Wa and the Kokang are ethnic Chinese, and some of them have linkages to the Burmese Communist Party (BCP) that collapsed in 1989. All the ethnic groups in the Alliance have also maintained an informal political economy with China, specifically Yunnan province. Consequently, China has taken a keen interest in the peace process and nominated a high ranking diplomat to deal with the issue. However, the three parties involved in the process - the Myanmar government and the military, the Northern Alliance, and China-retain both convergent and divergent interests and agendas.

This article identifies how the ethnic peace process in Myanmar has morphed over the last year. It seeks to identify the major changes, the parties involved in the process, and their interests and agendas. Through this discussion, the dynamics of the ongoing and fluid process and possible outcomes that may be realized given the present trajectory will be identified. This article is divided into 
five main sections. The first section provides a brief history of the peace process up to the signing of the NCA in October 2015. The second section identifies the major developments since then and especially those leading up to the formation of the Northern Alliance in October 2016. The third section identifies China's interests and role in the peace process, and the fourth section identifies the issues of convergence and divergence among the three parties to the process. The final section concludes the article and identifies possible long-term outcomes.

\section{A Brief History of the Peace Process}

The peace process owes its origins to the military caretaker government that replaced Ne Win's BSPP government in 1989. The collapse of the BSPP government that was preceded by the 1988 student demonstration for democracy left the military vulnerable to internal political turmoil. The situation was compounded by the fact that the Burmese Communist Party (BCP) collapsed at the same time from factional infighting. Arising from the second collapse was the formation of ethnic armies that comprised ex-fighters from the BCP. The most important of these were the UWSA and the Myanmar National Democratic Alliance Army (MNDAA-Kokang) located along the Sino-Myanmar border. The military government swiftly deflected this new internal threat by signing bilateral peace agreements with these armies under fairly liberal terms. Led by General Khin Nyunt who then headed the powerful Military Intelligence Agency, the deals allowed for the control of contiguous territory, the retention of weapons, and the requirement for the military to serve advance notice of movement into these areas (Ganesan 2013). Similar deals were subsequently signed with a total of sixteen armed groups by 2004. The military hoped that through an admixture of political negotiations and economic development it could persuade the groups to disarm and settle the situation over time. And, as part of the settlement, it hoped to integrate the ethnic fighters and the military into a Border Guard Force. This plan was only partially successful and even then only with the smaller groups that had little bargaining power. The larger groups like the Kachin, Kayin, Shan, and Wa rejected it outright.

The breakthrough in the peace process came during the Thein Sein government that was elected into office in 2010. The new government consolidated the existing bilateral agreements and worked hard to incorporate the larger remaining groups into a similar ceasefire. And in order to achieve this goal, the government established the Myanmar Peace Center (MPC) and appointed $\mathrm{U}$ Aung Min as the lead negotiator with supporting legitimacy and an administrative staff. This centralized control over the process from October 2012 led in turn to the inclusion of three new groups into the ceasefire process-the Karen National Union (KNU), the Karenni National Progressive Party (KNPP), 
and the Chin National Front (CNF) (Ganesan 2014). Drawing on the success of this development, the government also announced its intention to consolidate the bilateral agreements into a Nationwide Ceasefire Agreement (NCA). Unfortunately though, of the sixteen groups that had signed such ceasefires, only eight of them eventually acceded to the NCA in October 2015, just towards the end of the government's term of office (Ganesan 2015). The reforms initiated by the government, including better treatment of the political opposition, the freeing of a large number of political detainees, and the right of return for political exiles with guaranteed amnesty, also helped the ceasefire process. These developments were instrumental in lifting a wide range of international sanctions which had been imposed in 1993 and enlarged in 2003 when the military government detained Aung San Suu Kyi, the symbolic leader of the political opposition.

While the consolidation of the peace process was a significant step forward for the government and the country, there were a number of setbacks to the process as well. The first was the collapse of the bilateral agreement with the Kachin Independence Organization (KIO) in June 2011 and the resumption of often intense fighting. This hostility complicated the peace process since the KIO had a significant representation in the UNFC that brought the ethnic armed groups together for negotiations with the government. The KNU, which also had a strong influence in the organization, resigned from it prior to signing the $\mathrm{NCA}$, and this development had a displacement effect that strengthened the position of the KIO. Some of the non-signatories drew closer to the KIO over time and this was especially true of the Arakan Army (AA), the TNLA-Palaung, and the MNDAA (Kokang). This development was complicated by the fact that the UWSA, which controlled a huge swath of territory, argued that its bilateral agreement was working perfectly well and stayed aloof from the NCA altogether. Finally, in March 2015, Peng Jia Sheng, the leader of the MNDAA who had been ousted from the country in 2009, staged a brazen attack on the town of Laukkaing in an attempt to return to power. The military was caught off guard, suffered a large number of casualties, and, thus, became determined to defeat the group and exclude it from any ceasefire agreement. Hence, while the Thein Sein government achieved a measure of success in consolidating the peace process, there were some setbacks on the ground as well.

\section{Developments after the 2015 NCA}

The National League for Democracy (NLD)'s stunning victory in the November 2015 election meant that it would steer the peace process following the defeat of the previous government. Suu Kyi, who headed the NLD, clearly indicated that her government's foremost priority was the peace process and the conclusion of a Twenty-First Century Panglong Agreement. This Agreement is a reference to the 
1947 agreement signed by her father, General Aung San, which attempted to unite the country prior to political independence. General Aung San was especially keen to unite the highlands where many of the ethnic minorities resided and the lowlands that were politically consolidated by the British under colonial rule. In referencing this historical document, Aung San Suu Kyi meant to convey the impression that it was time to return to the spirit of unification and mutual goodwill and trust. However, for the ethnic armed groups, the Agreement was also a reminder of broken promises and decades of fighting waged against them. Importantly, the pact made by General Aung San in 1947 offered some groups the possibility of political secession should the Union fail after a two year trial period. Consequently, invocation of the historical document contained both promise and peril.

The NLD government dealt with ethnic issues from a broader structural perspective. It began with the creation of a Ministry of Ethnic Affairs despite downsizing the government. Importantly, an ethnic Mon was appointed as Minister. Additionally, all the states and regions had ministers for the position drawn from ethnic minorities in those areas. The government has reorganized the MPC into the National Reconciliation and Peace Center (NRPC) and moved it from Yangon to Naypyitaw. To retain control over the process, Suu Kyi has designated her personal physician and confidant, Dr. Tin Myo Win, as the new chief negotiator (Ganesan 2017). He has in turn met with groups that were previously sidelined by the military for involvement in fighting, including the MNDAA, TNLA, AA, as well as the UWSA. And Suu Kyi herself met with a delegation from the UNFC to signal the government's renewed engagement of the major players in the peace process.

The culmination of all these meetings was the staging of the Twenty-First Century Panglong Conference in Naypyitaw in August 2016. While the three groups that were sidelined by the military were not on the invitee list and the UWSA stormed out of the meeting citing unacceptable protocol, many more groups were invited to make the meeting much more inclusive. Such groups included representatives from political parties and civil society groups. To raise the profile and legitimacy of the event, the government also invited United Nations Secretary-General Ban Ki-moon. The involvement of international dignitaries and members of the diplomatic corps was, however, something that the previous Then Sein government had done as well. This first meeting was meant to be followed by a second one six months later, but the subsequent meeting was delayed and only held in May 2017. By then however, the situation on the ground had already changed considerably.

The first and most important of the changes was the government's sustained engagement of the KIA which involved military offensives in Kachin state. Similarly, it also regularly engaged the MNDAA and TNLA in the Shan states. These developments impacted the structuration of the peace process in turn, and 
led to a consolidation of like-minded "northern groups" clustered in the Shan and Kachin states and weakened the UNFC. ${ }^{1}$ It also had the unintended consequences of drawing the UWSA into the fold and creating a new Northern Alliance led by the Wa.

While the fighting between the military and the armed wing of the KIO, the KIA, was not a new development, the ferocity of the fighting certainly was. After intense air and artillery bombardments, the military announced the capture of Gideon Post in December 2016. This Post, which is located on high ground, has strategic significance in that it has a commanding view of Laiza, where the KIO is headquartered. The KIA's elite mobile brigade that defended the Post was decimated and its loss was meant to serve as a warning to the KIA and the non-signatories that a military solution to the conflict would privilege the army. Then, in a seeming response to the stepped up offensives in late 2016, a coalition comprising the KIA, MNDAA, and TNLA attacked the Shan town of Muse along the border with China in October. The government again declared a state of emergency in the area and broadened the fighting in mop up operations in pursuit of fighters of the MNDAA in particular. It was also at this time that that four rebel groups-the KIA, MNDAA, TNLA, and AAannounced the formation of the Northern Alliance to coordinate their activities. This Alliance has expanded since then and now includes a total of seven groups including the UWSA, Wa National Organization (WNO), KIA, MNDAA and TNLA, AA, National Democratic Alliance Army (NDAA-Mongla Group), and the Shan State Progressive Party (SSPP- North). And following a meeting at the UWSA headquarters in Panghsang in April 2017, the UWSA has announced its leadership of this Alliance as well as the formation of a new negotiating team, the Union Political Dialogue Negotiating Committee (UPDNC) (Lun Min Mang 2017). Simultaneously, it has rejected the NCA as the terms of reference for the peace process and offered its own version.

This new alignment and grouping has a number of implications worth noting. The first of these is that the UNFC, which used to articulate the interests of the non-signatories, has now been severely weakened by the withdrawal of the northern groups (Kyaw Kha 2017). While new smaller groups have entered the fold to raise the numbers, the UNFC lacks the clout it used to command in the past and will no longer be taken seriously by the government as a major negotiation partner. In fact, the larger groups within the UNFC like the New Mon State Party (NMSP) and the Karenni National Progressive Party (KNPP) have in the past indicated interest in signing onto the NCA. This position is at least in part necessary to avoid military offensives against the smaller groups that have much fewer combatants. The NMSP has a troop strength of about 1,000 soldiers, the KNPP about 600, the Lahu Democratic Union (LDU) about 150, and the Arakan National Council (ANC) about 100 (Kumbun 2017). The UNFC's territory is also removed from that of the Northern Alliance and buffered by 
territory controlled by the military. Finally, it was reported that General Min Aung Hlaing, during a visit to Thailand, persuaded Thai Prime Minister Prayuth Chan-ocha to put pressure on the UNFC which has its headquarters in the northern Thai city of Chiangmai.

While the Northern Alliance has collectively brought the Wa, Kokang, Kachin, and northern Shan groups into greater cooperation and alignment, its impact on the peace process remains to be seen. In fact, the Alliance itself is an unholy and convenient marriage of sorts since the KIA has in the past collaborated with the government in its fight against the BCP (in other words, the Wa and Kokang ethnic groups) and initially dismissed the leadership of the Wa as communist (Lawi Weng 2017). However, its major and ongoing conflicts with the military appear to have led to a change of heart. And while the Wa were in the past coy and remained aloof from the peace process, they now appear compelled to not only involve themselves but even lead the other groups. In this regard, the UWSA must have strategically calculated that there is strength in numbers in a worst case scenario and that if larger groups like the Karen and the Kachin were part of the process or militarily defeated, it could remain the weak outlier in the broader process and attract unnecessary negative attention to itself.

The other interesting dynamic is that the military is in a state of active combat and conflict with the KIA, MNDAA, TNLA, and AA who are a part of the Northern Alliance. How far the Alliance will hold and defend the collective interest of its members remains to be seen. Hence, although the Wa have offered leadership to the Northern Alliance, they are not involved in the military conflict, not yet at least. And the position of the Alliance that the NCA cannot form the basis for the peace process is likely to fall on deaf ears as far as the government and the military are concerned. Both parties are far into the process and have made it abundantly clear that peace is to be negotiated in reference to the NCA (Horsey 2017). While the military and the government may have differences in approaching the peace process, the military retains control over key ministries in the government that are related to the conflict-Defense, Border Areas, and Interior. Additionally, the military is above parliamentary scrutiny and not in the habit of reporting its activities to Parliament. Its decision to militarily defeat the MNDAA, TNLA, and AA is firm, which is why the three groups were not invited to the Twenty-First Century Panglong Conference in the first place (Htet Naing Zaw 2017). Membership in the Northern Alliance is unlikely to change the position of the military with regard to these three groups. On the other hand, it is entirely possible that the KIA and the military may salvage their collapsed peace deal and the military and the government may work out a deal with the Wa as well. What the military appears unwilling to concede is the creation of a Wa state as demanded by the UWSA for fear of losing control over the territory and setting a bad precedent for the other groups (Nyi Lwin Ne Pwint 2017). In fact, the UWSA even lobbied for control over border areas and immigration, a function 
that is typically a central government prerogative in even the most liberal federal states. In this regard, some of the ethnic armed groups appear to have a weak and unrealistic understanding of the dynamics of a federal state for which they so stoutly lobby (Taylor 2015).

\section{China's Interests and Role in the Peace Process}

China has traditionally had an important bilateral relationship with Myanmar. Part of the reason for its importance is the long and porous 2,200 kilometer border that both countries share. Hence, from a strategic and security perspective, the bilateral relationship is an important one (Ganesan 2011). Historically, the Chinese Communist Party provided support to the $\mathrm{BCP}$, and the Wa and Kokang are ethnic Chinese groups who speak Mandarin and use the Chinese Yuan as their currency. China has also had both formal and informal political and economic arrangements with other northern groups like the Kachin and the Shan. Many of these communities span across the border into China's Yunnan province as well.

During the period following the collapse of the BSPP government to the time of the elected Then Sein government, Myanmar was subjected to wide ranging international sanctions. China was also internationally isolated then after the Tiananmen Square Incident in 1989. Consequently, both countries were in similar political straits and the Myanmar military government sought domestic political legitimacy through economic and infrastructural development of the country. China, which has traditionally rejected the idea of conditionalities on trade and investments, was therefore in a unique situation at that time to strengthen relations with Myanmar; in fact, from 1989 to 2010 when the sanctions regime was in place against Myanmar, the bilateral relationship between China and Myanmar blossomed. Other important reasons for China's courtship of Myanmar was the country's wealth of raw materials like timber and oil, and the possibility of harnessing hydroelectric power from dams along the Salween and Irrawaddy Rivers (Aung Shin 2017). Finally, Myanmar has a long coastline along the Indian Ocean that would grant China access to another strategic shipping and trading route in line with its new Belt and Road Initiative (BRI) launched by President Xi Jinping. Myanmar and China have a strong bilateral economic relationship and China has traditionally been a large investor in Myanmar. This was especially so when Myanmar was subjected to the international sanctions regime. A recent statement from the Ministry of Commerce in June 2017 noted that bilateral trade between the two countries is valued at $\$ 10$ billion annually and accounts for some 30 percent of all foreign trade for Myanmar (Nilar 2017). It was also revealed in Parliament recently that China owns a disproportionate 44 percent of Myanmar's external debt (Soe Min Htike, Nyein Zaw Lin, and Myo Min Htet 2017). 
In light of all the aforementioned reasons, China retains a natural interest in its bilateral relationship with Myanmar. It has also worked towards enhancing the bilateral relationship and recently signed five bilateral agreements with Myanmar (Chan Mya Htwe 2017). However, more recently, and in particular with the formation of the new Northern Alliance, it has undertaken an active and direct role in the peace process. Chinese interest in the peace process and the NCA has always existed, and since many of the ethnic armed groups do not trust the Myanmar government and the military, they were always keen on meetings being hosted outside the country. Chiangmai, Thailand, which is home to a large Myanmar community and where the UNFC is headquartered, and Yunnan province in China, which is readily accessible to many of the northern ethnic armed groups, were frequent venues for meetings. And from 2013, the Chinese government not only encouraged the armed groups to sign the NCA but also sent high ranking officials to the meetings to indicate China's strategic interests in the meetings. In fact, over time, China began to acquire a seemingly proprietary attitude towards the peace process and indicated unhappiness when diplomats from the EU and Japan were invited to the signing of the NCA in October 2015. ${ }^{2}$

On the Myanmar side of the equation, the military has long acknowledged the presence of a northern faction from as early as 2013 (see footnote 1). And, in fact, high ranking military officials often regarded this faction as recalcitrant and unwilling to sign onto the peace process. This faction was also accused of being influenced by China. In other words, Myanmar policy-makers and the military regard these northern groups as beholden to China and sometimes actively working against Myanmar's national interests (Horsey 2017). Consequently, the formal announcement of the formation of the Northern Alliance was perhaps an expected development on the part of the Myanmar military. The process may well have been hastened by fighting against the KIA, TNLA, MNDAA, and AA, but it was well within the realm of possibility before, at least as far as the military was concerned. Importantly, the MNDAA, which launched the attacks on Laukkaing in March 2015 and Muse in October 2016, was accused of operating out of China. The leader of the MNDAA, Peng Jia Sheng, sought refuge in China after being defeated in 2009, and then later returned to reclaim the Kokang region. Hence, although conflict in the northern areas typically led to thousands of refugees crossing the border into Yunnan province in China, Myanmar leaders often regarded China as providing sanctuary to the leaders of these groups as well. ${ }^{3}$ And China has traditionally accommodated these refugees by providing them with food and shelter until the situation stabilizes and they return. Consequently, although such charges are not made in the public domain, there is a trust deficit in the relationship. In a recent interview, a ranking official from the town of Lashio also mentioned problems arising from the long border with China that include human and drug trafficking. ${ }^{4}$

More recently, China has offered the services of Sun Guoxiang, who holds 
the rank of Chinese Special Envoy for Asian Affairs, to be directly involved in the peace process. In the past he helped broker meetings in Kunming, Yunnan province between the northern groups, the Myanmar government, and peace negotiators. Most recently he has played a much more active role as an intermediary between the Myanmar government and the ethnic armed groups. It was a result of his shuttle diplomacy and pressure that the Northern Alliance attended the second Twenty-first Century Panglong Conference on short notice. It was reported that the Northern Alliance team members were flown to Naypyitaw aboard a chartered flight from Kunming with the blessing of Beijing (Irrawaddy News 2017). It is likely that he will continue to play a major role in brokering talks between the Northern Alliance and the Myanmar government. The most recent senior Chinese official to visit Myanmar to discuss wide ranging issues was Song Tao, Head of the International Liaison Department of the Communist Party of China, in August 2017 (Global New Light of Myanmar 2017). While China has always maintained that it encourages all the armed groups to sign the NCA and to work within the terms of the Agreement, this approach has been rejected by the Northern Alliance. Notwithstanding this situation, there can be no doubt that China has significant leverage over the Northern Alliance and in particular the Wa and Kokang groups since without China's support they can be choked off by the Myanmar military. Consequently, the withdrawal of Chinese support will constitute an existential threat to these groups. At the same time, these groups can be used as leverage to exact concessions from the Myanmar government, especially over difficult trade and investment issues. And since China's involvement in Myanmar is growing as part of its Belt and Road Initiative, there may be possibilities for compromise down the road in the long-term.

\section{Convergent and Divergent Interests among the Major Parties}

All parties to the peace process have indicated that they desire peace rather than continuous conflict. Realistically though, both peace and conflict have winners and losers. Peace would certainly benefit the country and the government as well as the ethnic minorities who have in the past been marginalized and displaced. Yet, some gain through the current situation as well. For example, the military can claim legitimacy and importance on the basis of threats to security and territoriality. And some of the larger ethnic groups with their own political economy and extractive industries have in the past benefitted from control of territories and resources as well. Similarly, the Wa have benefitted from virtually running their own territory without any interference from the government or the military. Consequently, a much more nuanced assessment of the ongoing situation is required rather than the simple assumption that all parties desire peace. The more important question will be: peace on what terms? 
The Myanmar peace process appears to have three major parties involved in the negotiations and outcome. Outwardly, these are the signatories to the NCA, the non-signatories, and the government. However, this simple equation obscures a number of other important realities and details. The first of these is that the non-signatories were one cohesive group, but, as explained above, this group has just split into two. The first is the remaining members of the UNFC and more recent entrants while the Northern Alliance is now a second major group by itself. In fact, on account of the size and relative importance of the UWSA and the KIA, the Northern Alliance now has pride of place. Conversely, the UNFC, which used to be the major interlocutor representing the non-signatories to the NCA, has been marginalized. Notwithstanding this role reversal, the Northern Alliance does not have the legitimacy previously enjoyed by the UNFC. And the simple reason for this development is that the military is currently in a state of intense conflict with four of the groups in this Alliance. The first of these is the KIA which has been fighting the military since 2011 and the other three groups are the MNDAA, TNLA, and AA that have been fighting the military since March 2015. The November 2016 attack on the border town of Muse that was claimed by the Northern Alliance has further isolated them as a dialogue partner. And it is for this reason that the military is disinterested in including the MNDAA, TNLA, and AA in any peace negotiations and why these three groups were not invitees to the first Twenty-first Century Panglong Conference. The KIA, on the other hand, despite fighting the military, did have a previous bilateral ceasefire agreement with the government that broke down.

The differences between the signatories and the non-signatories as a collective group are also stark. Although they regularly meet and exchange ideas, typically in Chiangmai, the signatories, led by the KNU, generally work within the terms of the NCA. The recent party election in March 2017 significantly strengthened the hand of Saw Mutu Say Poe who is in favor of continued engagement within the terms of the NCA (Ye Mon 2017). And there have been repeated bouts of conflict between the signatories and the non-signatories as well. These have been most pronounced between the Revolutionary Council of the Shan States (RCSS), a signatory, and the TNLA. These skirmishes are typically over territory and freedom of movement since the armed groups often have overlapping claims. ${ }^{5}$

The Northern Alliance now stands as the most recalcitrant group from the military's point of view. Apart from the ongoing conflict between it and four members of the group, the leading member of the Alliance, the UWSA, has outrightly rejected the NCA and proposed an alternative framework for peace. Additionally, its demands for its own state and autonomy are an anathema to the military. And the NLD government, which is anxious to secure peace and make it the most important agenda item going forward, has little leverage over the military. This is in part because there is no parliamentary oversight over the 
military and the military retains pride of place in the country owing to the terms of the 2008 Constitution that structurally embed its power. It has 25 percent representation in the state as well as in the regional and national parliaments, and controls the three most important ministries related to the conflict. Additionally, it may also take over political control of the country in the event of threats to national security. In this regard, the military, rather than the government, is able to determine the pace and progress of the peace process. While there have been no public disagreements between the new government and the military, de facto power over the peace process is retained by the military. This must serve as a disincentive to the ethnic armed groups that have been fighting the same military for a very long time. Hence, although the NLD government has privileged ethnic groups and hopes to gain their trust in the process, the trust deficit between the armed groups and the military continues and structural improvements are not translated into sustainable policies on the ground.

External parties to the conflict have roles as well. While for the most part their role is to support and sustain the peace process, they have little leverage over the process. The United Nations, European Union, and Japan are major contributors to the peace process and offer advice and technical support, but they can do little beyond that. The United Nations in particular has been utilized by both the Thein Sein and NLD-led governments to legitimize the important agreements related to the peace process. However, actual initiatives derive from the domestic parties to the process-the armed groups and the military in particular. China is the only external party that appears to have real leverage on the ethnic armed groups and in particular the Northern Alliance. And this is understandable since without China's cooperation and/or collusion, these northern groups will simply be unable to operate. Yet, while China has publicly articulated support for the NCA and urged all parties to sign it, it also has national interests that extend well beyond the peace process. Such interests include important geopolitical and economic considerations, some of which are independent of the peace process.

\section{Conclusion and Possible Outcomes}

There have been major developments in the Myanmar peace process between the ethnic armed groups and the government in the last year. The most important of these developments is the withdrawal of the KIA from the UNFC, which has in turn weakened the latter's role as the interlocutor for the non-signatories of the NCA. While other smaller groups have taken the place of the groups that have withdrawn, they do not have the same standing and influence. Consequently, the UNFC has been downgraded from the important role that it previously played. The second major development is the formation of the Northern Alliance in late 
2016 that has brought together four groups that are actively fighting the Myanmar military-the KIA, TNLA, MNDAA, and AA. Additionally the UWSA, which in the past remained aloof from the peace process, has now assumed the leadership position within the Northern Alliance. While this development may consolidate and strengthen the northern groups, it may not necessarily yield a favorable response from the government or the military. The Northern Alliance's call to renegotiate the peace agreement and refusal to work on the basis of the NCA has put it at odds with the NLD-led government and the military. The new Alliance appears to be a cobbling of groups that smacks of a marriage of convenience. It allows the isolated UWSA to play a leadership role rather than be marginalized over time, and allows the four groups actively fighting the military to formally ally with the ethnic armed group with the largest standing army.

The Northern Alliance has also led to the significant involvement of China in the Myanmar peace process. While China has always maintained some interest in the process on account of geopolitical and strategic interests and the importance of its bilateral relationship with Myanmar, there appears to be new vigor in its efforts. The appointment of a senior diplomat to act as an intermediary between the Northern Alliance and the Myanmar government and military is a new development. And China's ability to persuade both the Northern Alliance and the Myanmar government for the former's last minute participation in the second Twenty-first Century Panglong Conference is an indication of China's interest and leverage in the process. Whether this leverage will assist in the peace process remains to be seen since China does have its own national interests to consider when dealing with Myanmar. Likewise, the Myanmar government and military are not particularly enthused with external brokerage of what is essentially an internal situation. Additionally, the military has always held the northern groups to be suspect in terms of their allegiance and alignment.

\section{Acknowledgments}

I would like to acknowledge that funding for this research was partly supported by a Peace Research Grant from Hiroshima City University.

\section{Notes}

1. The first reference to the "northern faction" was made during a meeting with a high ranking minister of the Then Sein government and his Director General at a meeting in Mandalay in mid-December 2013.

2. Information gleaned from an interview with a presidential adviser to the Thein Sein government in Yangon on September 15, 2015. 
3. Peace negotiators from the Myanmar Peace Center often suggested that Chinese mercenaries were involved in the fighting alongside with the MNDAA in March 2015 and often regarded China's role and influence over the northern groups as not being in Myanmar's interest.

4. Interview with the District Commissioner of Lashio at the Two Elephants Hotel in Lashio on September 4, 2017.

5. Information gleaned from an interview with a senior ceasefire negotiator on January 13, 2017 in Yangon.

\section{References}

Aung Shin. 2017. "Myanmar and China Sign Crude Oil Pipeline Agreement." Myanmar Times, April 11. https://www.mmtimes.com/national-news/25676-myanmar-andchina-sign-crude-oil-pipeline-agreement.html (accessed October 17, 2017).

Chan Mya Htwe. 2017. “The High Road to Warmer Myanmar-China Ties.” Myanmar Times, May 31. https://www.mmtimes.com/opinion/26204-the-high-road-to-warmermyanmar-china-ties.html (accessed October 17, 2017).

Ganesan, N. 2011. "Myanmar-China Relations: Interlocking Interests but Independent Output." Japanese Journal of Political Science 12 (1): 95-111.

Ganesan, N. 2013. "Interpreting Recent Developments in Myanmar as an Attempt to Establish Political Legitimacy." Asian Journal of Peacebuilding 1 (2): 253-274.

Ganesan, N. 2014. "The Myanmar Peace Center: Its Origins, Activities, and Aspirations." Asian Journal of Peacebuilding 2 (1): 127-141.

Ganesan, N. 2015. "Ethnic Insurgency and the Nationwide Ceasefire Agreement in Myanmar." Asian Journal of Peacebuilding 3 (2): 273-286.

Ganesan, N. 2017. “Appraising Myanmar's Democratic Evolution and Evolving Challenges.” Japanese Journal of Political Science 18 (1): 196-215.

Global New Light of Myanmar. 2017. "State Counsellor Receives Head of Int'l Liaison Department of Communist Party of China." August 5.

Horsey, Richard. 2017. "Myanmar's Peace Conference Leaves Talks on Uncertain Path.” Nikkei Asian Review, May 31. https://asia.nikkei.com/Viewpoints/Richard-Horsey/ Myanmar-s-peace-conference-leaves-talks-on-uncertain-path (accessed October 17, 2017).

Htet Naing Zaw. 2017. "Military Chief of Staff: Army Not Open to Talks with AA, MNDAA or TNLA." Irrawaddy News, March 1. https://www.irrawaddy.com/news/burma/ military-chief-staff-army-not-open-talks-aa-mndaa-tnla.html (accessed October 17, 2017).

Irrawaddy News. 2017. "Senior Chinese Official to Visit Myanmar." August 1. https://www. irrawaddy.com/news/senior-chinese-official-visit-myanmar.html (accessed October 17, 2017).

Kumbun, Joe. 2017. “UNFC: On the NCA Path.” Irrawaddy News, September 7. https:// www.irrawaddy.com/opinion/guest-column/unfc-nca-path.html (accessed October 17, 2017).

Kyaw Kha. 2017. “Four Ethnic Armed Groups Leave UNFC.” Irrawaddy News, July 3. 
https://www.irrawaddy.com/news/four-ethnic-armed-groups-leave-unfc.html (accessed October 17, 2017).

Lawi Weng. 2017. "The Rule of the Wa." Irrawaddy News, March 2. https://www.irrawaddy. com/opinion/editorial/the-rule-of-the-wa.html (accessed October 17, 2017).

Lun Min Mang. 2017. "New Wa-led Committee Pledges to Overcome Deadlock in Peace Process." Myanmar Times, April 21. https://www.mmtimes.com/national-news/25696new-wa-led-committee-pledges-to-overcome-deadlock-in-peace-process.html (accessed October 17, 2017).

Nan Lwin Hnin Pwint. 2017. "UWSA Politician: Wa to 'Continue Asking for Autonomous State.” Irrawaddy News, June 29. https://www.irrawaddy.com/in-person/uwsapolitician-wa-continue-asking-autonomous-state.html (accessed October 17, 2017).

Nilar. 2017. "Myanmar-China Trade Reaches 10 Billion Every Year." Eleven Newsmedia, June 14. http://www.elevenmyanmar.com/business/10025 (accessed October 17, 2017).

Soe Min Htike, Nyein Zaw Lin, and Myo Min Htet. 2017. “China Owns 44\% of External Debt: MP.” Eleven Newsmedia, June 29. http://www.elevenmyanmar.com/business/ 10287 (accessed October 17, 2017).

Taylor, Robert H. 2015. "Refighting Old Battles, Compounding Misconceptions: The Politics of Ethnicity in Myanmar Today.” ISEAS Perspective, March 2. https://www. iseas.edu.sg/images/pdf/ISEAS_Perspective_2015_12.pdf (accessed October 17, 2017).

Ye Mon. 2017. "General Mutu Say Poe Re-Elected as KNU Chair." Myanmar Times, April 10. https://www.mmtimes.com/national-news/25662-gen-mutu-say-poe-re-electedas-knu-chair.html (accessed October 17, 2017).

N. Ganesan is a Professor of Southeast Asian Politics at the Hiroshima Peace Institute in Japan where he has been since 2004. From 2011 to 2013 he held a concurrent invited Visiting Professorship at the National Graduate Institute for Policy Studies (GRIPS) in Tokyo. His research interests are in sources of interstate and intrastate tensions in Southeast Asia and his most recent major edited works include Conjunctures and Continuities in Southeast Asian Politics (2013) and Bilateral Legacies in East and Southeast Asia (2015). Since 2013 he has served as coordinator and trainer for the Myanmar civil service in collaboration with the Ministry of Information. He also serves in a similar capacity as a faculty member at Yangon, Mandalay, and Yadanabon Universities since 2015 with German funding. 
